\title{
A short introduction of new apple varieties obtained
}

\author{
Szabó, T. ${ }^{1}$ \& Soltész, M. ${ }^{2}$ \\ ${ }^{l}$ Fruit Growing and Extension Service, Non profit Co. Ltd. H-4244 Újfehértó, Vadastag 2. \\ ${ }^{2}$ Horticulural College, Kecskemét H-6000 Kecskemét, Erdei Ferenc tér 1-3.
}

Matika (M 5/98)
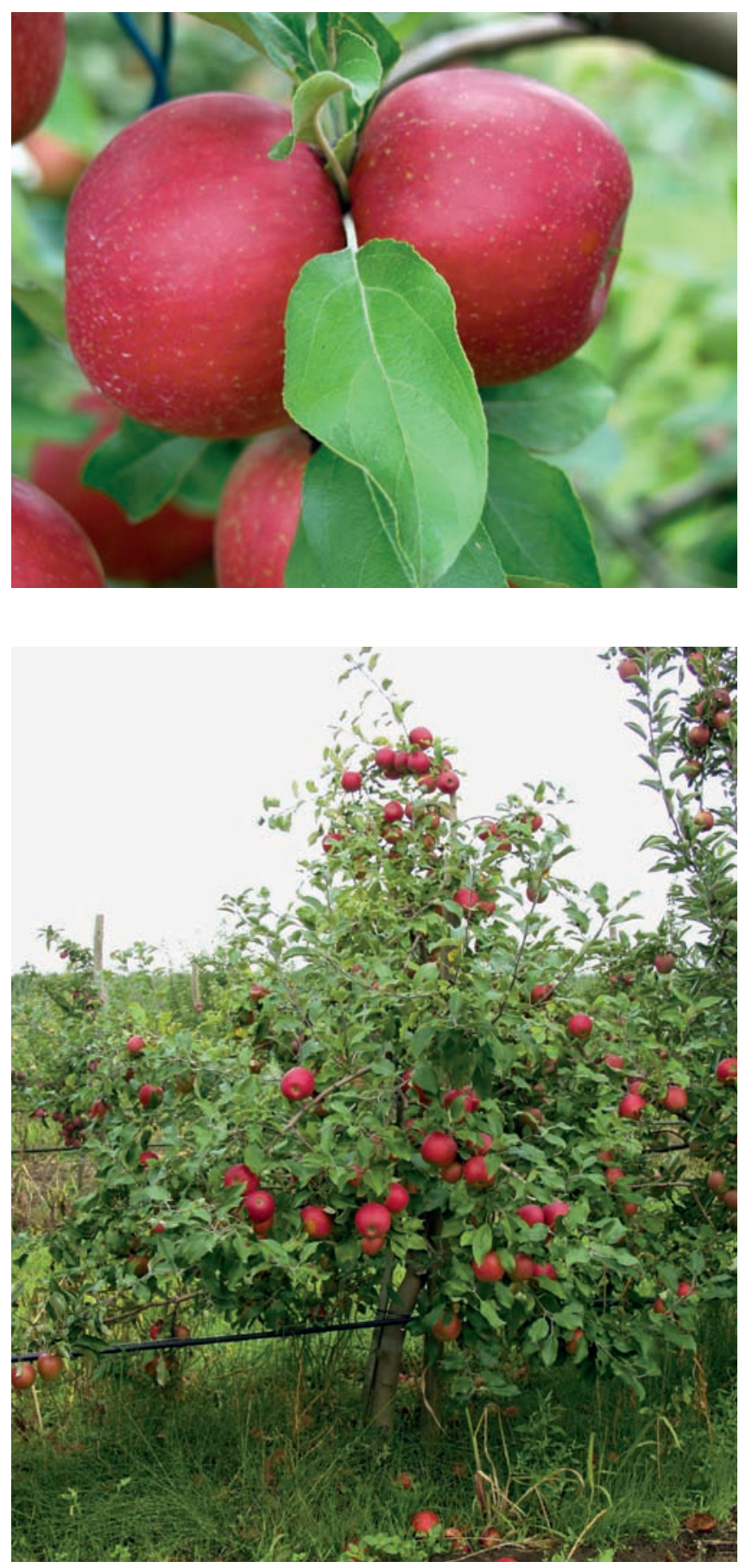

It is a seedling of 'Summerred' got by open pollination, selected by Tibor Szabó. Maturity is expected about the mid of August. The fruit is attractive, tasty, harvest could be finished in a single run. It is recommended for fresh consumption.

Fruit: Mediocre size, somewhat elongated, conic. Ground colour is light green, cover colour red washed or slightly striped, almost totally covering.

Fruit stem is short, calyx depression mediocre or small, closed and ribbed. The meat is white. The taste is faintly acidulous, sweet very sympathetic. For some weeks could be kept on the shelf.

The tree: Semi-vigorous or weakly growing, the crown is spreading horizontally or hanging. Shoots are semi thick, fruiting bodies are abundant, light brown. Fruits are grown on spears or long shoots.

Leaves are medium sized, broad, glossy, light green, abaxial surface is dense hairy. The petiole is of medium size, markedly coloured. Blooming time is early, pollination is easy with other varieties of the same blooming dates.

Fruiting starts early, first in the third year after planting. As a fruit of early autumn it is easy to sell. The virus free stock trees are held under plastic net.

\section{Soltadina (AS 8/31)}

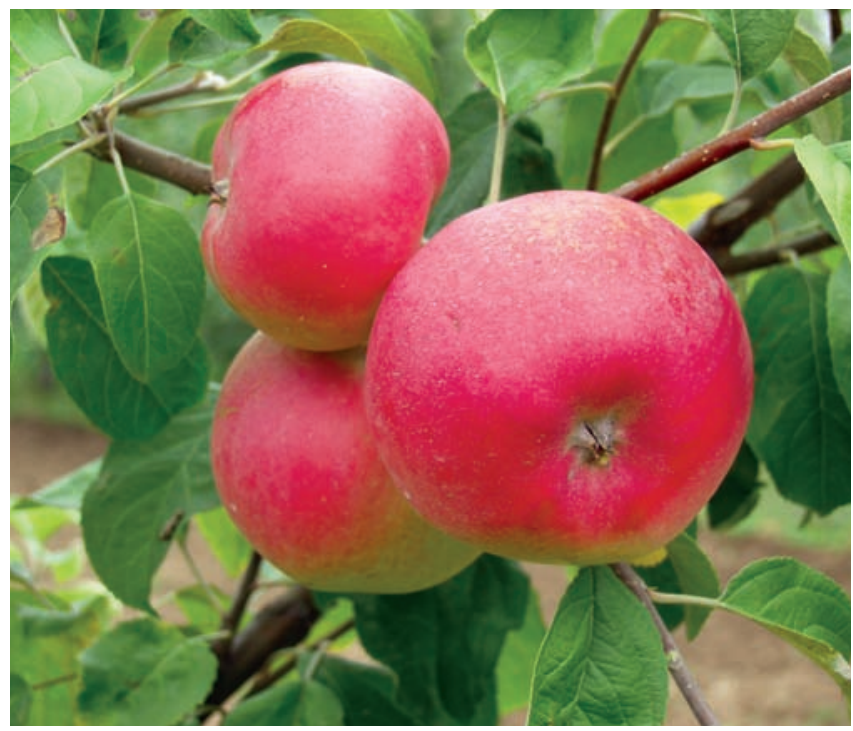


The open pollinated 'Idared' variety produced the seedling, which has been recognised by Miklós Soltész. Maturity ensues at the end of August. For fresh consumption and for processing is recommended.

Fruit is large, slightly flat spherical and faintly ribbed. Fruit stem is short-mediocre long and medium thick. Calyx depression is broad, open, ribbed. The peel is yellowish green with pink-red cover colour occupying almost the whole surface.

The meat is pale yellow, slightly acidulous, cracking, juicy, delicious. It could be kept in store until January.

The tree: Medium vigorous growth with slightly spreading crown. Shoots are light brown. Fruiting bodies are abundant. Flower buds grow also on shoots and spears. Leaves are broad, round, slightly undulated margins, light green, lacy, their abaxial surface is moderately hairy. The petiole is medium long, its anthocyanin colour is mediocre.

It starts early to fruit in $3^{\text {rd }}$ year after planting. It tolerates drought according to experiences. The virus free stock trees are held under plastic net.

\section{Dóra (M 10/97)}

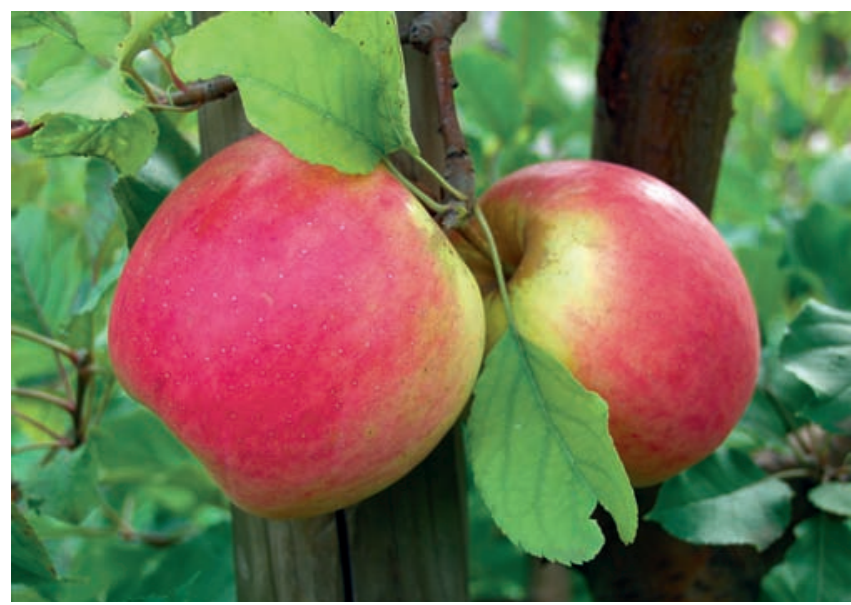

It is a seedling of 'Summerred' got by open pollination, selected by Tibor Szabó. Maturity is early October. Keeps until spring, and it is for fresh consumption and also for processing recommended.

The fruit is medium large to large, elongated tending to be egg shaped, slightly waxy. Light green basic colour covered with light red to three quarter, faintly striped. The calyx is open slightly ribbed. Fruit stem is medium long. The meat is yellowish white, medium firm, juicy, slightly acidulous, attractive.

The tree is medium vigorous, the crown is well ramificating, widely spreading. Shoots are medium thick, greenish brown, slightly hairy, covered by fruiting bodies. Fruit are mainly grown on shoots and spears. Leaves are elongated, dark green, their abaxial surface is moderately

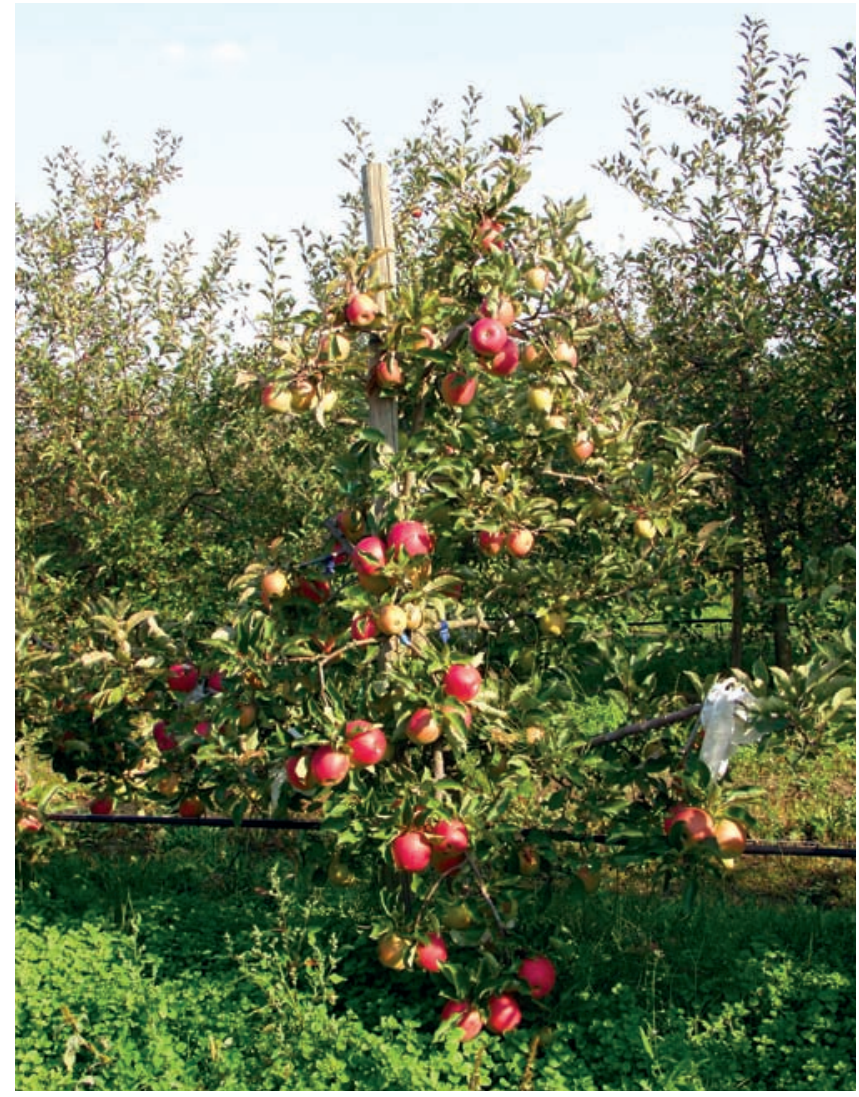

hairy. Petioles are long, medium coloured. Start of fruiting ensues early, yields are abundant and regular. Blooming time is early, fertilisation with other apple varieties is mutual.

The virus free stock trees are held under plastic net.

\section{Davidino (A 11/28)}

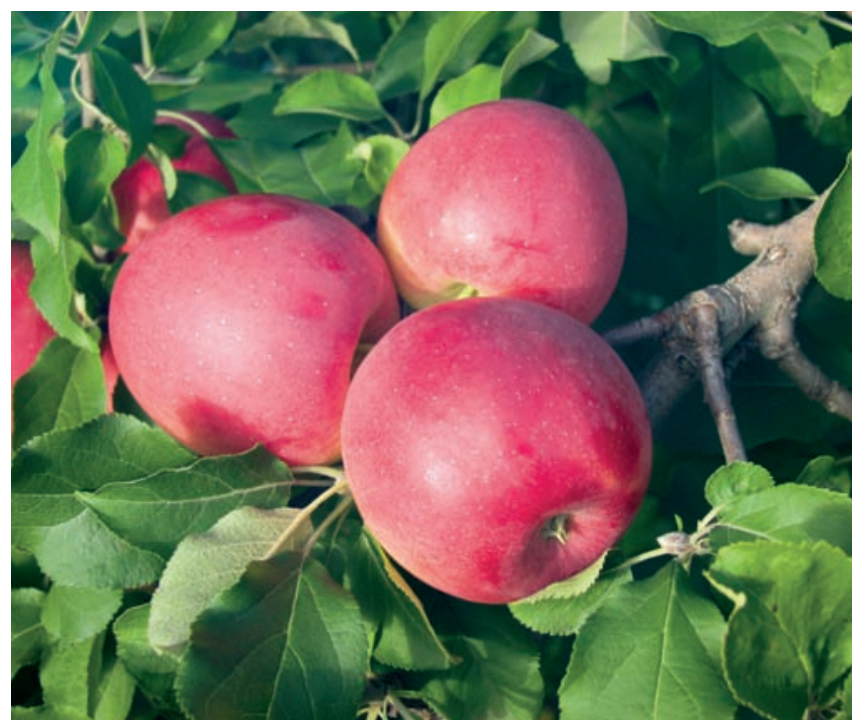

The open pollinated 'Idared' variety produced the seedling, which has been recognised and selected by Miklós Soltész. Harvest time is early October, keeps until spring for fresh consumption and processing recommended. 


\begin{tabular}{|l|c|c|c|c|c|c|c|c|c|}
\hline \multicolumn{1}{|c|}{ Variety } & $\begin{array}{c}\text { Blooming } \\
\text { date }\end{array}$ & $\begin{array}{c}\text { Blooming } \\
\text { intensity }\end{array}$ & $\begin{array}{c}\text { Picking } \\
\text { date }\end{array}$ & $\begin{array}{c}\text { Fruit mass } \\
(\mathbf{g})\end{array}$ & $\begin{array}{c}\text { Fruit } \\
\text { diameter } \\
(\mathbf{m m})\end{array}$ & $\begin{array}{c}\text { Yield } \\
\text { (kg/tree) }\end{array}$ & $\begin{array}{c}\text { Crown } \\
\text { volume } \\
(\mathbf{m 3})\end{array}$ & $\begin{array}{c}\text { Specific } \\
\text { yield } \\
\text { (kg/crown } \\
\left.\mathbf{m}^{3}\right)\end{array}$ & $\begin{array}{c}\text { Cover } \\
\text { colour } \\
(\%)\end{array}$ \\
\hline Gala & 04.22. & 3.9 & 09.22. & 148 & 71 & 23.1 & 4.2 & 5.8 & 68 \\
\hline Pinova & 04.21. & 4.6 & 10.06. & 164 & 74 & 13.2 & 1.4 & 8.9 & 73 \\
\hline $\begin{array}{l}\text { Davidino (A } \\
\text { 11/28) }\end{array}$ & 04.20. & 3.8 & 10.23. & 177 & 75 & 30.6 & 4.41 & 7.4 & 75 \\
\hline Dóra (M 10/97) & 04.21. & 4.2 & 10.22. & 188 & 80 & 23.3 & 2.0 & 11.6 & 73 \\
\hline Matika (M 5/98) & 04.20. & 4.3 & 08.18. & 179 & 78 & 21.6 & 3.0 & 7.3 & 82 \\
\hline $\begin{array}{l}\text { Soltadina } \\
\text { (AS 8/31) }\end{array}$ & 04.23. & 3.0 & 08.25. & 201 & 84 & 20.6 & 2.9 & 7.9 & 79 \\
\hline
\end{tabular}

Remark: Planting date: 1998. spring, Rootstock: M 26.

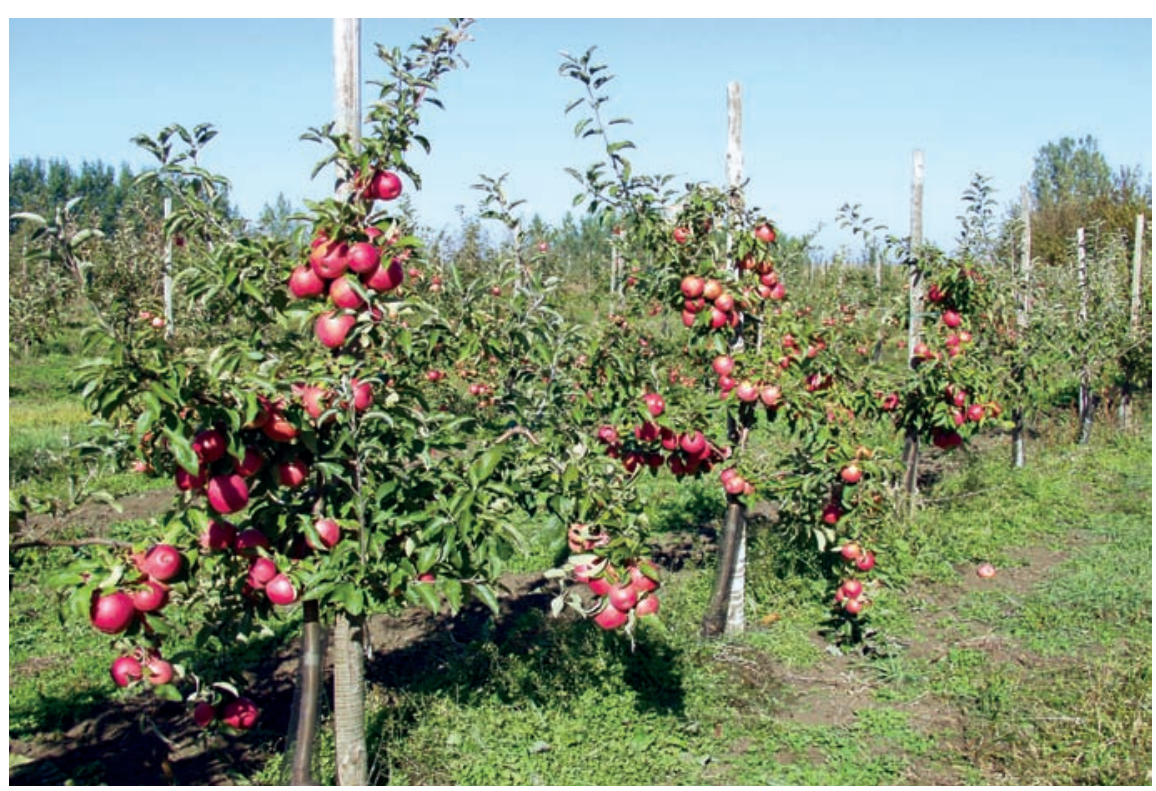

Fruit is of medium size or large with conic, accidentally open calyx, the depression is deep, slightly ribbed. The ground colour is yellowish green, cover is washed brownish red, slightly striped, moderately waxy. The cover colour occupies the three quarter of the surface. Lenticels are of medium size, scattered. The meat is yellowish white, sweet acidulous, medium juicy, attractive. Fruit stem is mediocre thick and long.

Th tree is medium vigorous or vigorous, branches are upward thriving, later spreading, densely ramified . Fruit are born on spears and also on long shoots. Shoots are medium thick, light brown, with clearly visible lenticels, on the upper part densely haired. Leaves are of medium size, long and narrow, especially serrate. They are glossy, dark green, the abaxial surface moderately haired. Petioles are medium long strong, red coloured. Drought tolerance was experienced. Start of fruiting is early. Blooming dates are early. Pollination is easy with other apple varieties for a regular abundant yield. The virus free stock trees are ready for use

\section{Acknowledgement}

Research was sponsored by TECH_08-A3/2-2008-0373 and TECH_08-A4/2-2008-0138 grants. 